\title{
THE RISKS AND REWARDS OF INVESTING IN THE STOCKS OF BANKRUPT COMPANIES
}

\author{
by \\ JOHN C. EDMUNDS and SUSAN E. MOELTER \\ NORTHEASTERN UNIVERSITY \\ and \\ GEORGE KUTNER \\ MARQUETTE UNIVERSITY
}

\begin{abstract}
This paper tracks the effect of reorganization on the equity issues of firms in Chapter 11 both before and after the filing date. It computes risk and return characteristics before and after filing . The calculations indicate that after filing the systematic risk of shares of Chapter 11 firms declines and the total variance rises. This result is important for investors interested in speculating in shares of companies in reorganization.
\end{abstract}

Securities of financially distressed firms are in fashion, due to the potential for large profits if they are successfully reorganized. Since 1980 more firms have filed for court protection of their assets than in any recent period. The recessionary environment of the early 1980's may account for this, but it is also notable that changes in the bankruptcy laws have made filing under Chapter 11 more palatable. The 1978 Bankruptcy Reform Act may have benefited holders of junior claims on financially distressed companies, giving them a better claim on future earnings.

This study tracks the effect of reorganization on the common stocks of firms filing under Chapter 11. It examines risk and return characteristics to measure the direction and magnitude of any risk change over time.

While there is considerable research supporting the view that capital markets correctly price shares of firms filing for reorganization under the pre-1978 law (1), little has been done to examine the effect of reorganization on the performance and risk measures of equities of firms filing under the new law.

For example Aharony, Jones, and Swary [1] demonstrated that both total risk (variance of returns) and unsystematic risk (variance of the market model residuals) of a sample of bankrupt firms were dramatically higher than the same measures for successful firms that were otherwise comparable. Their analysis ends when the firms in their sample file for protection. This study tracks risk and mean return measures both before and after firms file for Chapter 11 protection.

The paper is organized into four sections. The first reviews the legal 
environment for reorganization. The second and third sections describe the research techniques and the results. The paper concludes with implications for investors.

\section{LEGAL ENVIRONMENT}

The laws governing firms filing for Chapter 11 have two important implications for investors. First, because the law protects financially distressed firms from creditors, firms can continue to operate without harassment from creditors during reorganization. Shareholders are benefited because creditors are prevented from seizing the assets immediately. There is then time for the firm's value to recover. To illustrate, Golbe [6] showed that increasing the variance of returns increased the expected returns for shareholders, but not their downside risk. Although shareholders face the possibility of a total loss of their capital, they cannot lose more than 100\%. For that reason they have much to gain by allowing management the latitude to make aggressive moves.

Second, investors may earn large returns by purchasing the stocks of firms filing under Chapter 11 because the market may overreact to the announcement of the filing, or to scarcity of information during the reorganization period. Share prices of companies in Chapter 11 may not reflect their workout values. Mispricing can occur. It is hard to get financial information on firms while they are under court protection. Large institutional investors tend to exclude them from their portfolios because they cannot follow the proceedings easily.

The 1933 National Bankruptcy Law required that large public firms file for bankruptcy under Chapter 10 of the code. In a Chapter 10 proceeding, management was automatically ousted and replaced by a trustee, who assisted the court in devising a reorganization plan. Allocation of funds to creditors followed the "absolute-priority" rule: all senior claimants had to be paid in full before junior creditors received any compensation for monies owed them.

To avoid these rigid requirements many firms attempted instead to file under Chapter 11, which was intended to be used by small nonpublic firms -usually solvent -- that needed protection from creditors and time to develop a repayment schedule. In contrast to Chapter 10, informal negotiations between creditors and the debtor were the hallmark of Chapter 11 proceedings. During these negotiations management retained control of the firm and its operations. The relative leniency of Chapter 11 encouraged many large public firms to seek protection under its terms (2). Another reason companies favored filing under Chapter 11 was that under Chapter 10 the court process was long and expensive. To make reorganization an easier and less time-consuming process for all parties, Congress passed the 1978 Bankruptcy Reform Act. The law became effective for companies filing for reorganization after October 1, 1979. Its key provisions and effects are

1. Financially distressed firms no longer have to demonstrate balance sheet insolvency in order to petition for reorganization. Instead, they can file if they can not afford to pay their general creditors (3). Filing at an early stage helps prevent further deterioration of companies' financial positions. Investors may benefit because early filing should give a higher probability that a firm will successfully reorganize.

2. Management is allowed to retain control of the firm and continue opera- 
tion. This lessens the penalty of filing for bankruptcy. If fraud has occurred, a trustee can still be appointed by the bankruptcy judge.

3. Reorganization plans need not adhere to the "absolute-priority" rule. More compromise and informal negotiation can now take place between creditors and debtors. Shareholders would benefit since they now have a better chance of sharing in the reorganized firm's future.

RESEARCH METHODOLOGY

Data Collection

Approximately 200 firms filed for Chapter 11 between October 1, 1979, and December 31, 1982. The list was obtained from the Corporate Reorganization Department of the Securities and Exchange Commission [8]. From the list, a sample of 50 were chosen for which (a) return or price data were publicly available for at least two years prior to filing; and (b) financial information on the firms was given in Moody's Industrial Manual.

Return and price data came from two sources. Price data for listed stocks prior to filing was collected from the Center for Research on Security Prices (CRSP) data tapes. Over-the-counter (OTC) price quotes were collected from Standard \& Poor's Daily OTC Stock Price Record and converted into returns.

Stock return data were collected for a period two years before filing. Although some studies have shown that firms approaching bankruptcy experience changes in their stock returns up to five years before filing, Altman [4] shows that the final drop in price occurs within a month of filing. Altman's evidence indicates that the market is surprised by the bankruptcy announcement because the price drops by an additional 30 to 50 percent on the day of filing. Using return data for two years before filing covers the target time period. The sample was divided into two subgroups:

1. Group I included twenty-four firms for which daily return or price data was available for at least a year after filing, or until the firm was reorganized, merged into another firm, or liquidated.

2. Group II consisted of twenty-six firms for which end-of-the-month return or price data was obtainable for the same time periods as Group I.

Collecting post-filing prices for these shares was difficult. Trading was suspended in all but three of the companies that were listed on the New York Exchange before filing. Trading resumed on the Pacific Stock Exchange, or over the counter. Daily price data were collected from daily editions of the Wall Street Journal, and from Standard \& Poor's Daily OTC Stock Price Record.

For some companies only monthly stock price data were available. These were obtained from the pink sheet summaries provided by Merrill, Lynch, Fenner, and Pierce.

Measuring for Shifts in Risk

Fama [5] partitioned a stock's total risk into two components, systematic risk and unsystematic risk.

Estimates of systematic risk for each firm before and after filing were 
derived using the market model:

$$
R_{j t}=a_{j}+B_{j} R_{m t}+e_{j t}
$$

where $\quad R_{j t}=$ the daily or monthly return of firm $j$ at time $t$.

$\mathrm{B}_{j}=$ the average measure of systematic risk for firm $j$ during the time interval 1 to $t$ or beta.

$R_{m t}=$ the daily or monthly return on the market portfolio at time $t$.

$e_{j t}=$ the residual terms that are independently, identically, and normally distributed

The Standard \& Poor's 500 Stock Index returns were used as surrogates for the market portfolio returns.

The total variance of a firm's stock returns were also calculated before and after filing. Based on a paper by Levy [7], investors may find that the variance of returns is a better measure of risk than systematic risk because most investors hold only a few stocks in their portfolios.

RESULTS

Decrease in Systematic Risk (4)

The results of the above analyses illustrate that before filing 58 percent of the firms had beta estimates significantly different from zero at the .05 level, when tested. using the t-statistic, while after filing only 16 percent had beta estimates different from zero. This indicates that systematic risk of these securities declined after filing. This result is intuitively appealing but not conclusive, since the number of observations is too low.

We also found that 90 percent of the firms exhibited a significant change in beta after filing at the .05 level when tested using the t-statistic. Among the sample firms, 70 percent had a decrease in beta while 20 percent had an increase in beta post-filing. This means that these share prices did not track the market as closely as before.

The market model fit the data better before these firms filed under Chapter 11 than after. Using the F-test at the .05 level we found, before filing, the market return explained the return of 52 percent of the firms in the sample. After filing, however, the market return explained the return of only 10 percent of the firms in the sample.

The model was less able to explain the returns after filing because after filing for reorganization a firm goes through unpredictable changes in financial structure. Information about the firm's financial condition becomes harder to obtain, yet more critical than before to an investor determining the firm's value.

Increase in the Variance of Returns

Investors purchasing the securities of firms in Chapter 11 may find that an estimate of the total risk provides more valuable information about how a stock will perform than the conventional systematic risk estimate. Therefore for each sample firm we calculated a measure of total risk before and after 
filing by estimating the variance of returns. Eighty- two percent of our sample firms experienced an increase in the variance of their returns after filing for Chapter 11. Given the financial positions of these firms, this result is to be expected.

In addition, the average historical return for the two years before filing was negative for 78 percent of the 50 sample firms. This result is also to be expected, since shareholders do lose absolute wealth prior to a firm filing for Chapter 11. In contrast, the after-filing returns were positive for 78 percent of the firms. This is encouraging news for investors who may want to buy stocks of companies in reorganization.

The range of the post-filing returns for Group I was from $+1.52 \%$ per day to $-1.67 \%$ per day. On an annual basis, these returns translate into a high of +547 percent and a low of -601 percent. The range for Group II returns is similar, with a high of 381 percent to a low of -42 percent on an annual basis.

\section{IMPLICATIONS}

This study found that some stocks showed high returns after the filing date and some showed sharply negative returns. Systematic risk of individual stocks apparently decreased after the filing date, while variance of returns increased. The market model provided a good explanation of the returns on these stocks prior to the filing date, but after the filing date each stock seemed to uncouple itself from the broader market. After the filing date, the market model no longer explained the performance of these stocks. The course of reorganization proceedings, rather than the course of the broader market, appears to have more influence on value.

Risk-oriented investors should note that the average historical absolute returns of the stocks after filing were very high. Diversification would be indicated, because the range of returns was extremely wide. Also, conventional systematic risk estimates should be viewed with caution when measuring investment risk for this type of security. The variance of returns may be a more appropriate risk measure for developing adequate diversification.

The strategy of purchasing equal portions of all fifty firms in the sample on the days when they filed would have yielded a very high average annual return. This study does not resolve whether the return is high enough to compensate investors for the risk. Nor does it give any basis for predicting whether such a strategy would work well if it were tried commencing today. In absolute terms, however, the strategy would have given a return higher than can be easily achieved through other security purchases.

\section{FOOTNOTES}

1. See Altman [4], Westerfield [10]. and Aharony, Jones, and Swary [1] .

2. See Schnepper [9].

3. Altman [3] describes this lack of liquidity as technical insolvency. Insolvency, for bankruptcy purposes, occurs when a firm's total liabilities are greater than its total assets.

4. Appendices with detailed results on a firm by firm basis are available from the authors. 


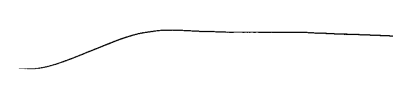

\section{REFERENCES}

[1] Aharony, J., Jones, Charles P., and Swary, Itzhak, An Analysis of Risk and Return Characteristics of Corporate Bankruptcy Using Capital Market Data, Journal of Finance. 35 (September 1980) : 1001-1016.

[2] Altman, Edward I., Discussion on Behavior of Firms in Financial Distress, Journal of Finance. 38 (May 1983) : 517-522.

[3] Altman, Edward I., The Financial Handbook. New York: Wiley, 1981, Chap. 35, pp. 3-47.

[4] Altman, Edward I., Corporate Bankruptcy Potential, Stockholder Returns and Share Valuation, Journal of Finance. 24 (December 1969) : 887-900.

[5] Fama, Eugene, Foundations of Finance. New York: Basic Books, 1976.

[6] Golbe, Debra L., The Effects of Imminent Bankruptcy on Stockholder Risk Preferences and Behavior, Bell Journal of Economics. 12 (Spring 1981): $321-328$.

[7] Levy, Hiam, Equilibrium in an Imperfect Market: A Constraint on the Number of Securities in the Portfolio, The American Economic Review. 68 (September 1978): 657.

[8] List of Public Firms Which Have Filed for Chapter 11 Since October 1, 1979, Securities and Exchange Commission, December 31, 1982.

[9] Schnepper, Jeff A., The New Bankruptcy Law. Reading, Mass: Addison Wesley, 1981.

[10] Westerfield, R., The Assessment of Market Risk and Corporate Failure, Wharton School of Finance: University of Pennsylvania, 1970. 